[Vicino Oriente XXV (2021), pp. 105-113]

\title{
CONTAINERS FOR THE DEAD: THE COSMOLOGICAL VALUE OF POTS IN MESOPOTAMIAN FUNERARY CONTEXTS
}

\author{
Nicola Laneri* - University of Catania \\ «Fire lives in the death of earth, air lives in the death of fire, \\ water lives in the death of air, and earth in the death of water». \\ Heraclitus, Fragment $76^{1}$
}

\begin{abstract}
Clay, fire and water are the three basic elements necessary for making pottery, but they are also three fundamental elements in framing the mythological dimensions of most of the societies inhabiting the world both in ancient and modern times (fig. 1). In his book La potière jalouse, ${ }^{2}$ Claude LéviStrauss clearly understood this important aspect in the creation of mythological stories among native American communities and highlighted the important role played by potters and pottery making in the fundamental process of human religiosity. Thus, in this paper, I will attempt to investigate the cosmological value entangled in pots to be used for funerary depositions in Mesopotamia between the $3^{\text {rd }}$ and $1^{\text {st }}$ millennia BC. It is especially during this later period that the use of clay containers became widely dispersed among Assyrian and Babylonian communities demonstrating the important role played by vessels in the construction of their funerary traditions.
\end{abstract}

Keywords: mortuary customs; ceramic containers; jar burials; Mesopotamia; funerary contexts

The relationship between clay, water and human life is a clear element evident in numerous Near Eastern religious texts, which document that the gods created mankind (e.g., the Mesopotamian Epic of Atra-hasis ${ }^{3}$ ) by the mixing of clay, water and divine blood. A similar connection is clearly evident in the Old Testament as well, particularly in the Genesis and the Book of Job (10:9), which state: «Remember that you have made me like clay; and will you return me to the dust». Moreover, according to Mesopotamian myths, ${ }^{4}$ when a person dies his/her soul (gidim in Sumerian and etemmu in Akkadian) will then reside in the Netherworld where it will eat dust and mud, and drink waste water. ${ }^{5}$

Thus, at the end of human life, the death of an individual appears as a natural process in which clay, water and the human body are first disentangled and then returned to their original status, whereas the 'soul' travels to the Netherworld. It then becomes the aim of the community of the living to support the soul's journey through libations and ritual practices as well as to respect the transformation of the body (and the disentanglement of the

This research was funded by the STORAGE project at the University of Catania.

After Robinson 1987.

Lévi-Strauss 1996.

Foster 1996.

See Katz 2003.

It is interesting to highlight that, as recently pointed out by Dina Katz (2014, 425-426) in referring to the creation of the cult statue for the dead, 'the Sumerian gidim, and Akkadian etemmu, not only signify the ghost in the netherworld, but also its physical, clay image' (italics mine). 
elements composing it) through the creation of a proper locale for its disposal (i.e., the grave).

It is for these reasons that the practice of burying the dead necessitated a locale that fittingly contained all the natural components of a human being in the earthly world according to Near Eastern mythological and religious stories. It is for these reasons that, since the Neolithic period, jar burials appear as one of the most common mortuary customs that marked the cultural traditions of ancient Near Eastern communities; in fact, due to the fact that a jar was made of clay and water, it represented a perfect metaphor for the relationship between ceramic containers and human bodies. ${ }^{6}$

\section{AN ANTHROPOLOGICAL PERSPECTIVE ON CERAMIC CONTAINERS AND MORTUARY CUSTOMS}

In the book La potière jalousie, ${ }^{7}$ Claude Lévi-Strauss defined the elements that, through their connection, established the mythological origin of clay and the art of pottery making among native Americans. In fact, in numerous native Americans mythological stories, clay is modeled into a container that serves a cultural purpose. The potter is a demiurge that, as the divine creator, shapes an incoherent material, as is clay. Thus, there is dialectic between clay and human beings that, in binary terms, is embodied in the relationship between a ceramic container that serves the purpose of cooking food and the human body that is a container for the food that is then expelled. In archaeology, a wide body of research has invested the relationship between the category of containers and practices of containing (fig. 2). For example, Christopher Tilley in his analysis of Europe Neolithic pottery states that «the pot is a container of fluids and substances which enter it and flow out of it, with the decoration on its surface, acting as a skin». ${ }^{8}$

Moreover, Carl Knappett, Lambros Malafouris and Peter Tomkins have further affirmed that:

«The idea of the body as a container may well be the emergent product of human interaction with containers and the bodily practices that surround them. This would mean that a deeply entrenched metaphor of the body as container might have originated in the extensive engagement of humans with the use and manufacture of containers, ceramic and otherwise. In other words, it can be argued that the relatively unstructured target domain of the human body becomes experientially grounded via containing technologies. Thus, a body can be understood as the metaphorical container of a soul or spirit». ${ }^{9}$

The metaphorical value of jars as containers for the spirit of the dead is proved by archaeological data available from ancient Minoan contexts. In this case, $30 \%$ of pithoi that are usually used for long-term storage are also used for the burial of human beings, reinforcing the metaphorical meaning of the vessels as long-term containers for either foodstuff or bodies.

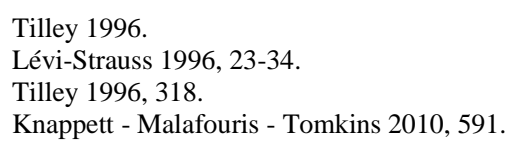


Even though among the Berawan of the Borneo Island (Indonesia) jars used for making rice wine are identical to those used for the primary storage of corpses, they are not reused for funerary purposes, but a metaphorical relationship is established none the less. In fact, for these communities «the grandmother/grandfather has picked out this jar for herself and doesn't want it used for rice wine». ${ }^{10}$

Thus, even if a metaphorical relationship between jars used for burials and those used for foodstuff can be envisioned when dealing with archaeological contexts, the assumption of reuse in burial is not always the case.

\section{THE MESOPOTAMIAN TRADITION OF JAR BURIALS}

The mortuary customs of ancient Near Eastern communities have been characterized by the burial of human beings in ceramic containers and, in certain cases, associated with funerary goods linked to their social role in life. This is especially the case of infant or child burials that, since prehistoric times, are usually deposited in double vases (generally two bowls) or cooking vases under house floors or walls. More complex is the tradition of jar burials used for adult funerary internments. In this case, as correctly pointed out by D.T. Potts, jar burials are «any burial in which the body was put into a large jar which was then sealed with a lid of wood, stone or terracotta, or with another vessel» ${ }^{11}$ (fig. 3). In Mesopotamia, although the earliest prehistoric mortuary customs are associated with the deposition of the dead in pits, the tradition of adult jar burials becomes more common starting from the Late Chalcolithic. In Northern Mesopotamia such a tradition can be recognized in the archaeological data available from sites like Oylum Höyük (in southeastern Turkey) and Tepe Gawra, where the presence of jar burials in levels XI-VIII represents about one third of the total types of inhumations. ${ }^{12}$

It is, however, starting with the $3^{\text {rd }}$ millennium $\mathrm{BC}$ that the increase in funerary variability in Mesopotamia also includes a further use of large pithoi to deposit adults accompanied with a few items (generally metal pins and jewels as well as small vessels and stone or clay necklaces). This is the case of the numerous $3^{\text {rd }}$ millennium BC sites located along the mid-upper Euphrates (e.g., Hassek Höyük, Hacinebi, Titriş Höyük, etc.). Additionally, together with a traditional inhumation of human bodies placed in a jar and then deposited in burial pits, at Gedikli in the Early Bronze Age III level cremated remains were found in funerary urns. ${ }^{13}$ At the site of Titriş Höyük (in the Urfa Plain) such a tradition of burying the deceased inside ceramic jars is increasingly visible in the late third/early $2^{\text {nd }}$ millennia $\mathrm{BC}$ contexts of house abandonment. ${ }^{14}$ Also in southern Mesopotamia, during the Early Dynastic period, at sites like Ur jar burials are present together with ceramic sarcophagi. ${ }^{15}$

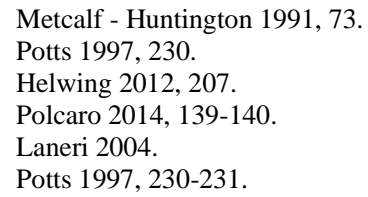


However, it is during the $2^{\text {nd }}$ and the $1^{\text {st }}$ millennia BC that the tradition of jar burials becomes a widespread funerary custom. In fact, thousands of jar burials have been recovered from late $2^{\text {nd }}$ and $1^{\text {st }}$ millennia $B C$ Mesopotamian contexts (as is the case of about 400 graves uncovered by Leonard Woolley at the southern Mesopotamian site of $\mathrm{Ur}^{16}$ ). In Syria such a tradition become a distinctive marker of the funerary customs at important sites like Mari, Ebla and Qatna. ${ }^{17}$ At Ebla, the funerary custom of burying the deceased in jars appears to have been mostly used for the burial of infants during the Middle Bronze Age I (as recognizable in the cemeterial areas discovered nearby city ramparts), whereas during the following phase MBA II jar burials are used for the deposition of adults together with the use of traditional pit burials; ${ }^{18}$ whereas at Mari, it is during the Middle Assyrian period that the tradition of burying the dead in ceramic containers is a very common funerary custom. ${ }^{19}$

Regarding the first millennium BCE, the use of jar burials will become a distinctive marker of Mesopotamian funerary tradition, and, as highlighted by Baker, in terms of grave types, the double pot jar burial is probably the most common type of ceramic funerary burials (fig. 4) as is the case of the southern Mesopotamian burials found at Uruk and at Babylon (i.e., type 1a and $1 \mathrm{~b}$ according to Baker's jar burial typology in Babylon between the mid- $2^{\text {nd }}$ and $1^{\text {st }}$ millennia $\mathrm{BC}^{20}$ ). According to Baker's typology (that is based on the analysis of the jar burials found at Babylon, Isin, Kish, Nippur, Sippar, Tell ed- Der, Tell el-Lahm, Ur and Uruk), other types of jar burials belonging to this specific southern Mesopotamian cultural context are bathtub coffins (type 2), large open-mouth jar burials (type 3), oval coffins (type 4), bowls (type 5) and bathtub bowls (type 6). This type of tradition is also recognizable further north in Neo-assyrian contexts ${ }^{21}$ and in other regions affected by Assyrian (first) and Babylonian (later) imperial conquests such is the case of southern Levant ${ }^{22}$.

\section{CONCLUSIONS}

As mentioned at the beginning of this brief contribution, the relationship between human life and clay is pivotal in creating ancient Near Eastern mythologies. In particular, in ancient Mesopotamian tradition this is recognizable in the section dedicated to the 'Creation of Mankind' in the famous Epic of Atra-hasis (i.e., the Babylonian story of the flood dated to ca. mid-XVII century BC, but also later copies are known):

«On the first, seventh, and fifteenth days of the month, Enki established a purification, a bath. They slaughtered Aw-ilu, who had the inspiration, in their assembly. Nintu mixed clay with his flesh and blood. That same god and man were thoroughly mixed in the clay. For the rest of the time they would hear the drum.

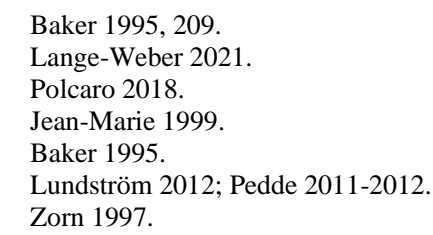


From the flesh of the god the spirit remained. It would make the living know its sign. Let he be allowed to be forgotten, the spirit remained. After she had mixed the clay, she summoned the Anunnaki, the great gods. The Igigi, the great gods, spat upon the clay». ${ }^{23}$

When such a connection was established and framed within a cosmological dimension then it would have been important to continue the dialectic between clay and human beings. In so doing, the act of containing the human body at the end of life was of fundamental importance through the creation of a meaningful container that could have had a cosmological value. It is for this purpose that the relationship between ceramic containers and human dead bodies acquires a higher cultural value among Near Eastern societies through the use of jar burials as part of the funerary custom of the community of the living. This is evident from the available archaeological data since the Neolithic, however it is during the $2^{\text {nd }}$ and $1^{\text {st }}$ millennia BC (and, especially, during the Neo-Assyrian and NeoBabylonia periods) that the use of jar-burials becomes a widespread funerary custom among Mesopotamian communities.

As recognizable in contemporaneous mythological stories (as is the case of the abovementioned Epic of Atra-hasis or the Biblical stories), such a connection between the human body and clay vessels both considered as containers (one for the human soul - etemmu -and the other for human food) needed to be maintained for eternity and the jar burial was the perfect solution to obtain such an objective (fig. 5).

\section{REFERENCES}

BAKER, $\mathrm{H}$.

1995 Neo-Babylonian Burials Revisited: S. CAMPBELL - A. GREEN (eds), The archaeology of FOSTER, B.

1996 Before the Muses: an anthology of Akkadian literature, Bethesda 1996.

HELWING, B.

2012 Late Chalcolithic Craft Traditions at the North-Eastern 'Periphery' of Mesopotamia: JEAN-MARIE, M Potters vs. Smiths in the Southern Caucasus: Origini 34 (2012), pp. 201-220.

1999 Tombes et nécropoles de Mari (Mission archéologique de Mari 5. Bibliothèque archéologique et historique 53. Institut français d'archéologie du Proche-Orient),

KATZ, D

2003 The Image of the Netherworld in Sumerian Sources, Bethesda 2003.

2014 'His Wind is Released' - The Emergence of the Ghost: Rite of Passage in Mesopotamia: A. Mouton - J. Patrier (eds.), Life, Death, and Coming of Age in Antiquity: Individual Rites of Passage in the Ancient Near East and Adjacent Regions (Uitgaven van het Nederlands Instituut voor het Nabije Oosten te Leiden 124), Leiden 2014, pp. 419- 437.

23 After Foster 1996, 168 
KNAPPETt, C. - Malafouris, L. - TOMKINS, P.

2010 Ceramics (as containers): D. HICKS - M.C. BEAUDRY (eds.) The Oxford Handbook of LANERI, N. Material Culture Studies, Oxford 2010, pp. 518-612.

2004 I costumi funerari della media vallata dell'Eufrate durante il III millennio a.C. (Dissertationes 4), Napoli 2004.

LANGE-WEBER, $\mathrm{S}$.

2021 Das Totenmahl in Syrien im 2. Jahrtausend v. Chr: Eine Untersuchung zur Bedeutung, Symbolik und Tradition eines altorientalischen Konzepts in philologischer, archäologischer und religionsgeschichtlicher Perspektive am Beispiel von Mari, Qattna und Ugarit (Qaṭna-Studien/Supplementa 4), Wiesbaden 2021.

LÉvi-STRAuss, C.

1996 The jealous potter, Chicago 1996.

LUNDSTRÖM, S.

2012 Concerning the Dead - How to Bury an Assyrian King? Possibilities and Limits of the Archaeological and Written Evidence in the Second and First Millenium BC: P. PFALzNER - H. NiEHR - E. PERnICKA - S. LANGE - T. Koster (eds.), Contextualizing grave inventories in the ancient Near East. Proceedings of the workshop at the London 7th ICAANE in April 2010 and an International Symposium in Tubingen in November 2010, both organized by the Tubingen Post-graduate school 'Symbols of the Dead' (Qatna Studien. Supplementa 3) Wiesbaden 2012, pp. 271-280.

Metcalf, P. - Huntington, R.

$1991 \quad$ Celebrations of death: the anthropology of mortuary ritual, Cambridge 1991.

PEDDE, F.

2011-2012 Die mittel- und neuassyrischen Gräber: Alter Orient aktuell 12 (2011-2012), pp. 44-45.

POLCARO, A.

2014 Fire and Death: Incineration in the Levantine Early-Middle Bronze Age cemeteries as mark of cultural identities, or as technical instrument of purification?: P. BIELIŃSKI - M. GAWLikowski - R. KolińSKi - D. ŁaWECKa - A. SoltysiaK - Z. WygnańsKa (eds.), Proceedings of the $8^{\text {th }}$ International Congress on the Archaeology of the Ancient Near East 30 April - 4 May 2012, University of Warsaw Volume 2: Excavation and Progress Reports, Posters, Wiesbaden 2014, pp. 137-148.

2018 Urban Landscape and Funerary Ideology in Old-Syrian Ebla: P. MATTHIAE - F. PINNOCK M. D'ANDREA (eds.), Ebla and Beyond Ancient Near Eastern Studies after Fifty Years of Discoveries at Tell Mardikh, Wiesbaden 2018, pp. 317-344.

PoTTS, D.T.

1997 Mesopotamian civilization: the material foundations (Athlone publications in Egyptology ROBINSON, T.M and ancient Near Eastern studies), Cornell University 1997.

1987 Heraclitus, Fragments: A Text and Translation with a Commentary (Phoenix Supplementary volume 22), Toronto 1987.

TiLley, C.Y.

1996 An ethnography of the Neolithic: early prehistoric societies in southern Scandinavia, Cambridge 1996.

ZORN, J.R.

1997 More on Mesopotamian Burial Practices in Ancient Israel: Israel Exploration Journal 47/3-4 (1997), pp. 214-219. 


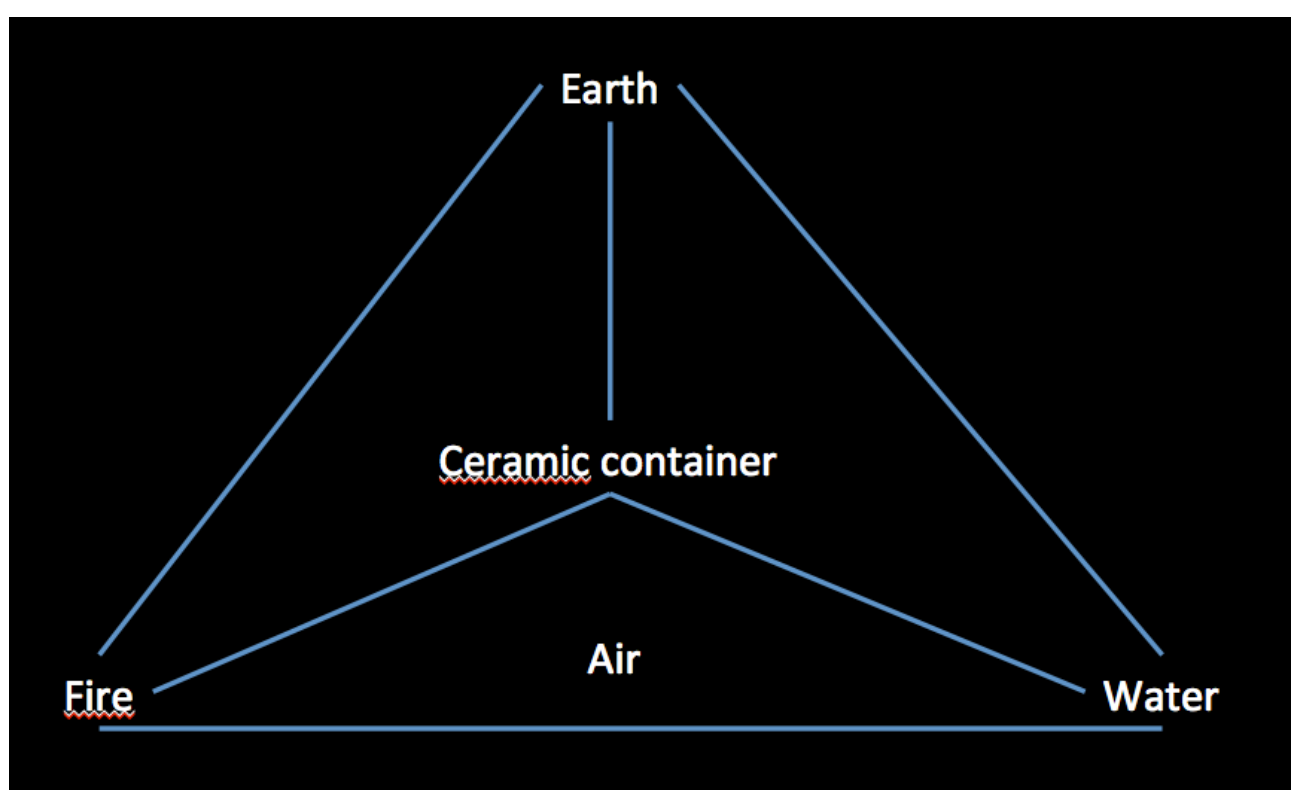

Fig. 1 - Graphic illustrating basic elements necessary for making pottery.

Ceramic container (vase) -- Clay $->$ extraction $->$ modeling $->$ cooking $->$ container

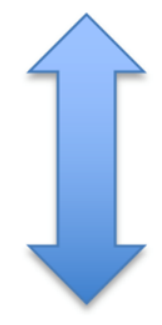

Human Body -- Food $->$ cooking $->$ digestion $->$ defecation $->$ excrement

Fig. 2 - Graphic illustrating the relationship between the category of containers and practices of containing. 


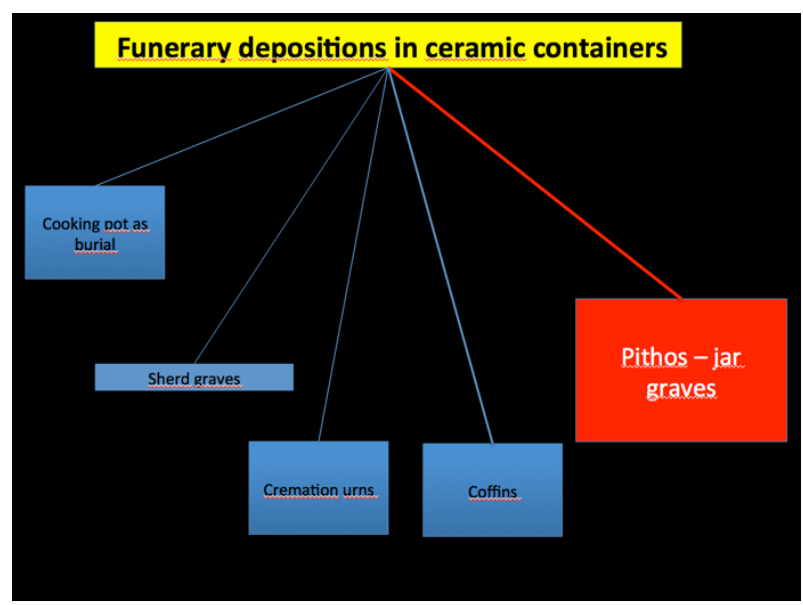

Fig. 3 - Graphic illustrating types of ceramic containers for burials.
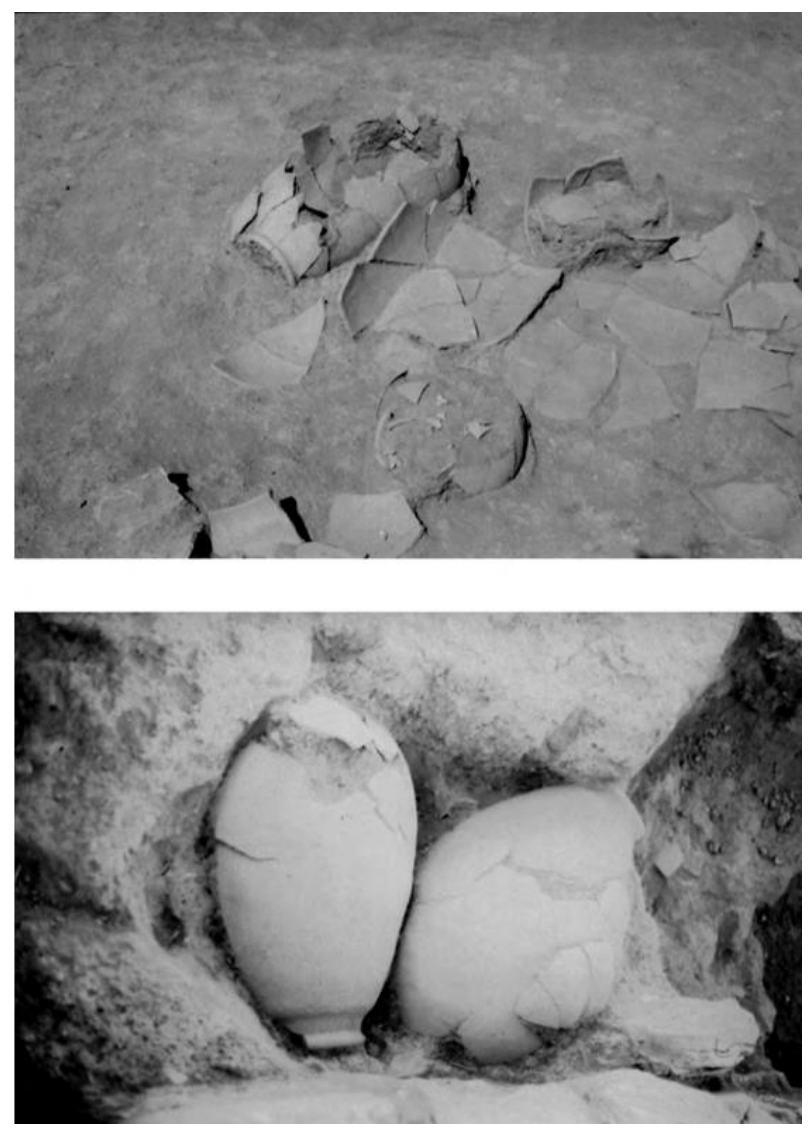

Fig. 4 - Late $3^{\text {rd }} /$ early $2^{\text {nd }}$ millennia BC jar burials from Titriş Höyük (Southeast Turkey). 


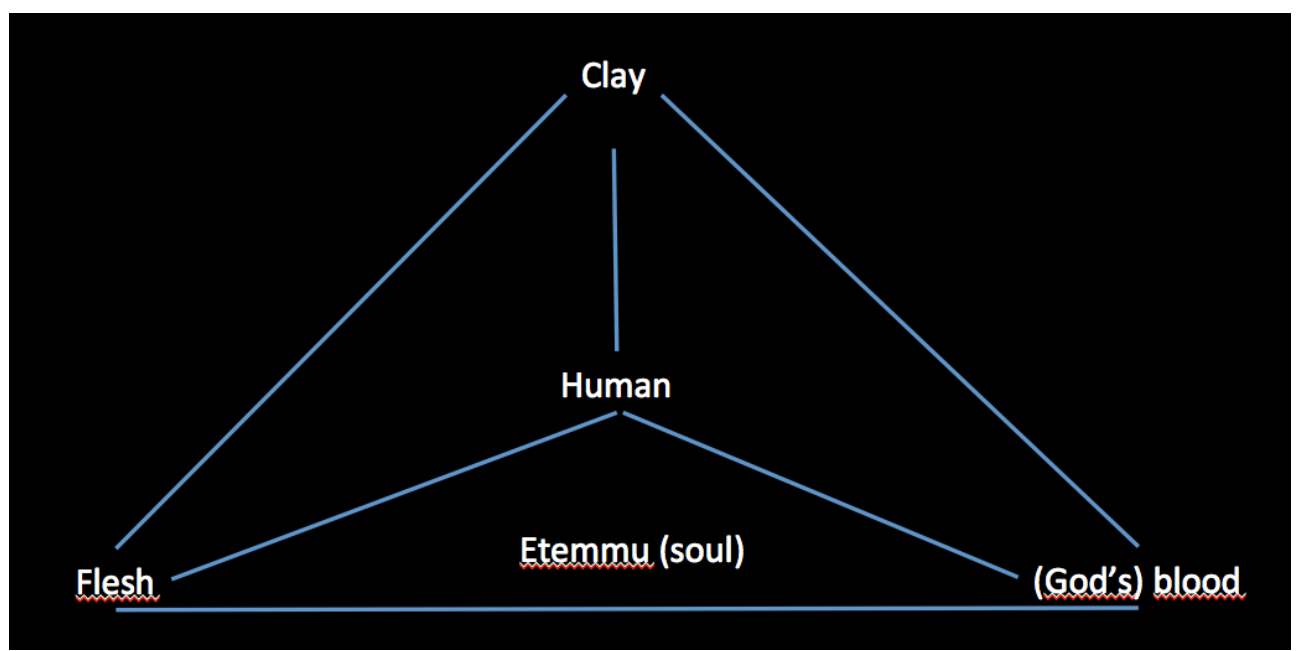

Fig. 5 - Graphic illustrating the connection between human body and clay vessels both considered as containers. 